\title{
GLOMUS TYMPANICUM PARAGANGLIOMA IN A 63-YEAR-OLD MALE - A RARE ENTITY IN THE MIDDLE EAR: A CASE REPORT
}

\author{
Filip Petrović1,2, Dragan Stojanov ${ }^{1,2}$, Nikola Živković2,3, Jovana Zdravković2, \\ Marta Petrović ${ }^{2}$ Dušan Milisavljević ${ }^{2,4}$, Zoran Radovanović1,2
}

\begin{abstract}
Glomus tympanicum paraganglioma arise from the glomus bodies that run with the tympanic branch of the glossopharyngeal nerve (Jacobson nerve). Although glomus tympanicum tumours are the most common primary neoplasms of the middle ear, these tumours are the rarest of head and neck paragangliomas. In most cases these benign tumours grow slowly, but can be locally aggressive. We present the case of small glomus tympanicum in a 63-yearold male patient with one year long history of pulsatile tinnitus and ear fullness as well as decreased hearing. On otoscopy, a pulsatile reddish mass was seen behind the tympanic membrane and Brown sign was elicited. Imaging revealed middle ear cavity mass on the cochlear promontory with strong post contrast enhancement. The knowledge of the clinical presentation, the imaging features and the differential diagnosis of the middle ear masses is necessary to establish the correct diagnosis. This case illustrates small size glomus tympanicum paraganglioma with typical clinical and imaging findings. Imaging and imaging based classification play most important roles in diagnostic and treatment planning in patient with glomus tympanicum paragangliomas.
\end{abstract}

Acta Medica Medianae 2019;58(3):97-101.

Key words: glomus tympanicum paraganglioma, imaging, classification

${ }^{1}$ Center of Radiology, Clinical Center Niš, Niš, Serbia

2University of Niš, Faculty of Medicine, Niš, Serbia

${ }^{3}$ Center for Pathology and Pathological Anatomy, Clinical Center

Niš, Niš, Serbia

${ }^{4}$ ENT Clinic, Clinical Center Niš, Niš, Serbia

Contact: Filip Petrović

Hajduk Veljkova 7, 18000 Niš, Serbia

Email: fpetrovic91@gmail.com

\section{Introduction}

Head and neck paragangliomas (also commonly referred to as glomus tumours or chemodectoma) are highly vascular lesions originating from the paraganglionic tissue, located at four typical locations: the carotid bifurcation (carotid body tumours), along the vagus nerve (vagal paragangliomas), and in the jugular fossa and tympanic cavity (jugular and tympanic paragangliomas) $(1,2,3)$. These tumours originate from the chief cells of the paraganglia, or glomus bodies, located within the wall (adventitia) of the jugular bulb, and can be associated with either the auricular branch of the vagus nerve (Arnold nerve) or the tympanic branch of the glossopharyngeal nerve (Jacobson nerve). Paraganglia develop from the neural crest and are believed to function as chemoreceptors (4).

Paragangliomas account for $0.6 \%$ of all neoplasmas of the head and neck and $0.03 \%$ of all neoplasms (5).

These lesions are histologically similar to the pheochromocytomas that may develop in the adrenal medulla, but unlike pheochromocytomas, head and neck paragangliomas rarely secrete cathecholamines (6).

In most cases they are benign neoplasms; overall less than $10 \%$ of all paragangliomas have been cited to be malignant (5).

Tumours in the area of the middle ear cavity are called glomus tympanicum paragangliomas; they arise from the glomus bodies that run with the tympanic branch of the glossopharyngeal nerve (Jacobson nerve). Although glomus tympanicum tumours are the most common primary neoplasms of the middle ear, these tumours are the rarest of head and neck paragangliomas $(7,8,9,10)$.

\section{Case report}

We present a 63 year old male patient with one year long history of pulsatile tinnitus in the right ear. The tinnitus was accompanied by ipsilateral ear fullness. Last few months patient noted decreased hearing on the right side. There was no history of 
headache, vertigo and facial weakness, as well as otorrhea and ear pain. No other comorbidities were present.

On otoscopy, a pulsatile reddish mass was seen behind the tympanic membrane and Brown sign was elicited. Audiometry revealed conductive hearing loss in the right ear. The left ear had normal audiometric finding.

The patient came to our department after clinical examination which was made few days before imaging. The first diagnostic method in our department was computed tomography (CT).

CT demonstrated oval middle ear cavity mass on the cochlear promontory. The diameter of the mass was $8 \mathrm{~mm}$. There were no ossicular chain destruction and no evidence of bony erosion. The vestibule, cochlea and semicircular canals had normal morphology. The carotid canal had normal configuration and it was intact. There was no evidence of dehiscence of the internal jugular vein bulb. No abnormalities were seen along the course of the facial nerve canal. The postcontrast CT study resulted in intense enhancement of the cochlear promontory mass, which was well-defined and slightly bulged the tympanic membrane.

The next diagnostic tool was magnetic resonance imaging (MRI). The mass demonstrated low T1 weighted and high T2 weighted signal intensity on MR images. It presented intense enhancement after contrast administration.

According to the CT and MR presentation of the middle ear cavity mass, as well as clinical presentation, otoscopic examination and audiometric findings, we made the diagnosis of glomus tympanicum paraganglioma.

The patient underwent excision of the glomus tumour via a transcanal approach. Follow up few months after surgery showed the absence of tinnitus and improvement of hearing.

Histopathological examination showed branching vascular canals separated by stroma. In the stroma, grouped glomus cells surrounding blood vessels were seen. Nuclei of these cells were small and showed low mitotic activity. Final histopathology was consistent with glomus tumour.

\section{Discussion}

Glomus tumours have an annual incidence of 1 per 1.3 million people (11). These tumours are commonly seen in $5^{\text {th }}$ and $6^{\text {th }}$ decade of life, with a female predominance (12).

Our patient is male in the $7^{\text {th }}$ decade of life, with right sided glomus tympanicum paraganglioma.

Paragangliomas are typically described as benign and slow growing. Glomus tympanicum may be confined to the middle ear or may spread along the paths of least resistance to the mastoid or even up to the nasopharynx. In our patient the tumour was on cochlear promontory in the middle ear cavity, without spread to surrounding structures.

Glomus tympanicum may present with pulsatile tinnitus and hearing loss, and our patient had these symptoms. Other symptoms may include head- ache, vertigo and facial weakness, as well as otorrhea and ear pain. Tachycardia, hypertension, tremors and headaches can indicate the possibility of a functional tumour. None of these symptoms were present in our patient.

On otoscopy, a pulsatile reddish mass was seen behind the tympanic membrane and Brown sign was elicited. Brown's sign is the pulsations elicited by pneumatic compression of the tumour. All these signs were present in our patient.

Imaging is the primary modality of investigation for glomus tympanicum tumours. A combination of contrast enhanced computed tomography, magnetic resonance imaging and angiography is ideal for the diagnosis and localisation of glomus tumours.

Strongly enhancing mass at its site of origin is typical in the diagnosis of glomus tympanicum tumours (13).

CT is best for evaluation of bony erosion and destruction which is demonstrated in larger glomus tympanicum. Similar to CT, contrast enhanced MRI shows strongly enhancing soft tissue mass, which is typical for diagnosis, at characteristic locations (13, 14).

Multiple areas of high and low signal intensity on MRI, the so-called "salt and pepper appearance", originally described by Olsen et al. (15) can be seen within the larger lesion on T1 weighted and T2 weighted images. The "pepper" component represents the multiple areas of signal void interspersed with the "salt" seen as hyperintense foci (due to slow flow or hemorrhage) on both T1 weighted and T2 weighted images $(15,16)$. This feature is especially seen in larger paragangliomas, and was not seen in our patient, who had small glomus tympanicum tumour.

Angiography identifies the primary feeding vessels to the lesion, helps in detecting multicentric tumours and allows for possible preoperative embolisation. Angiography is imaging procedure which can confirm the diagnosis of a head and neck paraganglioma and some authors report that it is still the gold standard in detection of small paragangliomas $(15,17,18)$. Angiography shows the specific vascular supply of the paraganglioma (19). The ascending pharyngeal artery can be considered "the artery of the paraganglioma", because its branches can supply tympanic, jugular, vagal, carotid, and even laryngeal paragangliomas (20). Embolisation can be performed with angiography for preoperative devascularisation of the large tumour.

This diagnostic procedure was not performed in our case.

Surgical resection is the treatment of choice especially in small paragangliomas. The surgical approach depends on the size and extent of the tumour. Preoperative image based classification of glomus tympanicum paragangliomas is essential, since the operative approach will be chosen depending on the tumour stage (21).

The tympanic paragangliomas present usually like a small mass at the cochlear promontory, ossicular destruction is not common and is especially present in larger lesions. The extension of temporal bone destruction is important to classify those tu- 
mours. The two established classifications of temporal bone paraganglioma are based mainly on tumour size with special emphasis on intracranial extension as a decisive factor for resectability. Paragangliomas of the temporal bone, as well as the glomus tympanicum paragangliomas are usually staged according to the classification by Fisch (22) and Glasscock and Jackson (23).

In the present case, the tumour was limited on the cochlear promontory, without any destruction of the ossicular chain and surrounding bone, and it was classified as Fisch type A and Glasscock - Jackson type 1 , with recommendation for surgical treatment. Type 1 glomus tympanicum tumours are generally approached by transcanal tympanotomy (24).

Surgery remains the treatment of choice in an otherwise healthy patient who desires the immediate cure of disease provided by a total resection. Preoperative embolisation is necessary in patients especially when a tumour diameter is larger than 3 $\mathrm{cm}$ (4). It can reduce intraoperative blood loss significantly.

Paragangliomas may be treated with either surgery or radiotherapy. The goal of any treatment is to control tumour growth and prevent further neurological compromise and it is important to select the intervention with the greatest chance of tumour control and the lowest risk of complications (25).

However, radiotherapy is often used for larger slow growing tumours with an aim to restrict growth in unresectable tumours. Preoperative evaluation with CT, MRI and angiography has been proposed as essential for optimal planning (26).

The differential diagnosis considerations for the middle ear mass include benign neoplasms and diseases (adenoma, endolymphatic sac tumours, choristoma, cholesteatoma, cholesterol granulomas) and malignant neoplasms (squamous cell carcinoma, adenocarcinoma, sarcoma). Adenomatous tumours (mixed pattern type) of the middle ear manifest as soft-tissue masses in the tympanic cavity, usually without destruction of surrounding osseous structures. These tumours may enhance intensely following the intravenous administration of contrast material (27). Endolymphatic sac tumours of the temporal bone arise from the region of vestibular aqueduct. Although they may closely resemble glomus tumours, their origin from the vestibular aqueduct is a useful discriminating characteristic. They are frequently quite large at the time of presentation, demonstrate lytic changes in the temporal bone and characteristically have regions of hyperintensity on T1-weighted sequences on $\mathrm{MRI}(28)$.

Cholesterol granuloma occurs secondary to nonspecific chronic inflammatory changes and it can be seen in the middle ear cavity. Hemorrhage, cholesterol, and granulation tissue are the hallmarks of the lesion and account for its appearance on MRI (29). Patients most often present with conductive hearing loss and a vascular appearing retrotympanic mass on physical examination. On CT, the imaging appearance is nonspecific with a soft tissue middle ear mass. Findings on MRI are more characteristic, demonstrating a nonenhancing middle ear mass which is hyperintense on both $\mathrm{T} 1$ and $\mathrm{T} 2$ sequences secondary to hemorrhagic blood products (30). Care must be taken to compare pre and postcontrast T1 sequences, since the lesions are hyperintense on both which may be mistaken for enhancement. With adjacent inflammation, there may be thin peripheral enhancement.

Cholesteatoma also can be found in the middle ear cavity, but on the MRI it exhibit specific findings with restriction of diffusion and does not demonstrate the postcontrast enhancement. Cholesterol granuloma and cholesteatoma usually are not located at cochlear promontory.

Glomus tympanicum tumours are usually described as arising on the promontory (31).

Cavernous hemangioma is a rare benign neoplasm of the middle ear, which can rarely cause tinnitus and mimic a glomus tympanicum clinically, radiographically and otoscopically (32). Middle ear hemangiomas should be differentiated from the more common geniculate ganglion hemangiomas (33), which usually present with facial nerve palsy (34) but may rarely cause pulsatile tinnitus $(35,36)$. The diagnosis is often possible only at surgery. The literature review revealed one case of hemangioma localized on the promontory of the middle ear confirmed by histopathological study as capillary hemangioma (37).

In our case the diagnosis is made after clinical examination and imaging, and confirmed after histopatological examination.

\section{Conclusion}

In conclusion, we report the case of a rare entity - glomus tympanicum paraganglioma in a 63 old male patient with one year long history of pulsatile tinnitus and ear fullness as well as decreased hearing. Imaging revealed middle ear cavity mass on the cochlear promontory with no ossicular chain destruction and no evidence of bony erosion. On otoscopy, a pulsatile reddish mass was seen behind the tympanic membrane and Brown sign was elicited. The imaging features demonstrated strongly enhancing mass. All these signs are important and can help to make the diagnosis of the glomus tympanicum tumour. The knowledge of the clinical presentation, the imaging features and the differential diagnosis of the middle ear masses is necessary to establish the correct diagnosis. Imaging based classification is essential in management of the treatment choice. 


\section{References}

1. Jensen NF. Glomus tumors of the head and neck: anesthetic considerations. Anesth Analg 1994;78: 112-9. [PubMed]

2. Baysal BE. Hereditary paraganglioma targets diverse paraganglia. J Med Genet 2002;39:617-22. [PubMed][CrossRef]

3. Rao $A B$, Koeller KK, Adair CF. Paragangliomas of the head and neck: radiologic-pathologic correlation. Radiographics 2002;19:1605-32.

[PubMed][CrossRef]

4. Pluta RM, Iuliano B. Glomus Tumors, eMedicine, Jun 122008 .

5. Lee JH, Barich F, Karnell LH. National cancer data base report on malignant paragangliomas of the head and neck. Cancer 2002;94:730-7. [PubMed][CrossRef]

6. Johnston F, Symon L. Malignant paraganglioma of the glomus jugulare: a case report. Br J Neurosurg 1992; 6(3):255-9. [PubMed][CrossRef]

7. Cheng A, Niparko JK. Imaging quiz case 2. Glomus tympanicum tumor of the temporal bone. Arch Otolaryngol Head Neck Surg 1997;123(5):551-552.

8. Mafee MF, Raofi B, Kumar A, Muscato C. Glomus faciale, glomus jugulare, glomus tympanicum, glomus vagale, carotid body tumors, and simulating lesions. Role of MR imaging. Radiol Clin North Am 2000;38 (5):1059-76. [PubMed][CrossRef]

9. Carlson ML, Sweeney AD, Pelosi S, Wanna GB, Glasscock ME, Haynes DS. Glomus tympanicum: a review of 115 cases over 4 decades. Otolaryngol Head Neck Surg 2015;152(1):136-42. [PubMed][CrossRef]

10. Alaani A, Chavda SV, Irving RM. The crucial role of imaging in determining the approach to glomus tympanicum tumours. Eur Arch Otorhinolaryngol 2009; 266(6):827-31. [PubMed][CrossRef]

11. Moffat DA, Hardy DG. Surgical management of large glomus jugulare tumours: infra- and trans-temporal approach. J Laryngol Otol 1989;103(12):1167-80. [PubMed][CrossRef]

12. Rao AB, Koeller KK, Adair CF. From the archives of the AFIP. Paragangliomas of the head and neck: radiologic-pathologic correlation. Armed Forces Institute of Pathology. Radiographics 1999;19(6):1605-32. [PubMed][CrossRef]

13. Coulier $B$, Mailleux $P$, Lefrancq $M$. Images in clinical radiology. Glomus tympanicum: CT diagnosis. JBRBTR 2003;86(6):359. [PubMed]

14. Van den Berg R, Van Gils AP, Wasser MN. Imaging of head and neck paragangliomas with three-dimensional time-of- flight MR angiography. AJR Am J Roentgenol 1999;172(6):1667-73. [PubMed][CrossRef]

15. Olsen WL, Dillon WP, Kelly WM, Norman D, BrantZawadzki M, Newton TH. MR imaging of paragangliomas. Am J Roentgenol 1987;148(1):201-4. [PubMed][CrossRef]

16. Som PM, Curtin HD. The parapharyngeal space. In: Som PM, Curtin HD, editors. Head and neck imaging. $3^{\text {rd }}$ ed. St. Louis: Mosby;1996.p.915-51.

17. Patetsios P, Gable DR, Garrett WV. Management of carotid body paragangliomas and review of a 30-year experience. Ann Vasc Surg 2002;16:331-8.

[PubMed][CrossRef]

18. Van den Berg R, Verbist BM, Mertens BJA, Van der Mey AGL, Van Buchem MA. Head and neck paragangliomas: improved tumor detection using contrastenhanced 3D time-offlight MR angiography as compared with fat-suppressed MR imaging techniques. Am J Neuroradiol 2004;25(5):863-70. [PubMed]
19. Van den Berg R, Rodesch G, Lasjaunias P. Management of paragangliomas: clinical and angiographic aspects. Interv Neuroradiol 2002;8:127-34. [PubMed][CrossRef]

20. Lasjaunias P, Berenstein A. Temporal and cervical tumors: branchial paragangliomas. Surgical neuroangiography. Berlin: Springer;1987.p.127-62. [CrossRef]

21. Antonitsis P, Saratzis N, Velissaris I, Lazaridis I, Melas N, Ginis G,et al. Management of cervical paragangliomas: review of a 15-year experience.Langenbecks Arch Surg 2006;391:396-402. [CrossRef]

22. Fisch U, Mattox D. Paragangliomas of the temporal bone. Microsurgery of the skull base, part 1. Stuttgart, New York: Thieme Company;1988.p.149-52.

23. Jackson CG. Basic surgical principles of neurotologic scull base surgery. Laryngoscope 1993;103:29-44. [PubMed][CrossRef]

24. Singh VK, Badhwar S, Souza JD, Indrajit IK. Glomus Tympanicum. MJAFI 2004;60:200-3. [CrossRef]

25. Gottfried NO, Liu KJ,Couldwell TW. Comparison of radiosurgery and conventional surgery for the treatment of glomus jugulare tumors. Neurosurg Focus 2004;17(2):22-30. [PubMed][CrossRef]

26. Galagali JR, Singh ID, Kumar S, Kumar Gupta A. Recurrent glomus jugulotympanicum: a case report. Int J Otorhinolaryngol Head Neck Surg 2016;2(1):4752. [CrossRef]

27. Lo WWM, Solti-Bohman LG. Tumors of the temporal bone and cerbellopontine angle. In Som PM, Curtin $H D$, editors. Head and neck imaging. $3^{\text {rd }}$ ed. St. Louis: Mosby; 1996.p.1516.

28. Schwartz JD,Harnsberger JH,Mukherji SK. The temporal bone. Radiol Clin North Am 1998;36:819-53. [PubMed][CrossRef]

29. Moonis G, Kim A, Bigelow D, Loevner LA. Temporal bone vascular anatomy, anomalies, and disease, with an emphasis on pulsatile tinnitus. In: Swartz JD, Loevner LA. Imaging of the temporal bone, 4th ed. New York: Thieme; 2009:289-91.

30. Martin N, Sterkers O, Mompoint D, Julien N, Nahum H. Cholesterol granulomas of the middle ear cavities: MR imaging. Radiology 1989;172(2):521-5. [PubMed][CrossRef]

31. Schuknecht HF. Pathology of the Ear. Philadelphia: Lea \& Febiger; 1993.p.452-60.

32. Tokyol C, YilmazMD. Middle ear hemangioma: a case report.Am] Otolaryngol2003;24:405-7. [CrossRef]

33. Hecht DA, Jackson CG, Grundfast KM. Managementof middle ear hemangiomas. Am J Otolaryngol2001; 22:362-6. [PubMed][CrossRef]

34. Lo WW, Shelton C, Waluch V, Solti-Bohman LG, Carberry JN, Brackmann DE, et al. Intratemporal vascular tumors: detection with $\mathrm{CT}$ and MR imaging. Radiology 1989;171:445-8. [PubMed][CrossRef]

35. Isaacson B, Telian SA, McKeever PE, Arts HA. Hemangiomas of the geniculate ganglion. Otol Neurotol 2005;26:796-802. [PubMed][CrossRef]

36. Friedman O, Neff BA, Willcox TO, Kenyon LC, Sataloff RT.Temporal bone hemangiomas involving the facial nerve. Otol Neurotol 2002;23:760-6.

[PubMed][CrossRef]

37. Karatas E, Durcu C, Baglam T. Promontory hemangioma mimics glomus tympanicum in the middle ear (promontory hemangioma). European Review for Medical and Pharmacological Sciences 2012;16(4 Suppl): 103-5. [PubMed] 


\title{
GLOMUS TYMPANICUM PARAGANGLIOM KOD 63 GODINE STAROG MUŠKARCA - REDAK ENTITET SREDNJEG UVA: PRIKAZ SLUČAJA
}

\author{
Filip Petrović1,2, Dragan Stojanov ${ }^{1,2}$, Nikola Živković2,3, Jovana Zdravković2, \\ Marta Petrović ${ }^{2}$, Dušan Milisavljević2,4, Zoran Radovanović1,2
}

\author{
${ }^{1}$ Centar za radiologiju, Klinički Centar Niš, Niš, Srbija \\ 2Univerzitet u Nišu, Medicinski fakultet, Niš, Srbija \\ ${ }^{3}$ Centar za patologiju i patološku anatomiju, Klinički Centar Nišs, Nišs, Srbija \\ ${ }^{4}$ Klinika za bolesti uva, grla i nosa, Klinički centar Niš, Nišs, Srbija
}

Kontakt: Filip Petrović

Hajduk Veljkova 7, 18000 Niš, Srbija

Email: fpetrovic91@gmail.com

Glomus tympanicum paragangliomi potiču od glomus tela lokalizovanih duž timpanične grane glosofaringealnog nerva (Jacobsonov nerv). Iako su glomus tympanicum tumori najčešće primarne neoplazme srednjeg uva, ovi tumori najređi su paragangliomi regije glave i vrata. U najvećem broju slučajeva ovi benigni tumori imaju spor rast, ali mogu biti lokalno agresivni. Prezentujemo slučaj malog glomus tympanicum paraganglioma kod 63 godine starog bolesnika muškog pola, sa jednogodišnjom istorijom puslatilnog tinitusa i osećajem punoće u uvu, kao i sa oslabljenjem sluha. Otoskopija je pokazala puslatilnu crvenu masu iza timpanične membrane kao i Brownov znak. Imidžing je pokazao masu srednjeg uva na kohlearnom promontorijumu sa izraženim postkontrastnim pojačanjem. Poznavanje kliničke prezentacije, imidžing karakteristika, kao i diferencijalne dijagnoze masa srednjeg uva, neophodni su za postovljanje tačne dijagnoze. Ovaj slučaj pokazuje glomus tympanicum paragangliom malih dimenzija sa tipičnim kliničkim i imidžing karakteristikama. Imidžing i imidžing klasifikacije igraju najvažniju ulogu u dijagnostičkom i terapijskom planiranju kod bolesnika sa glomus tympanicum paragangliomima.

Acta Medica Medianae 2019;58(3):97-101.

Ključne reči: glomus tympanicum paragangliom, imidžing, klasifikacija 